\title{
Çocuklar için özel gereksinim raporu başvurusu olan olguların özel gereksinim düzeyleri
}

\author{
Special need levels of cases with special need report admission for children
}

Merve Aktaş Terzioğlu, Ahmet Büber, Çiğdem Tanrıverdi, Hande Şenol

Gönderilme tarihi:13.04.2021

Kabul tarihi:21.05.2021

\section{Öz}

Amaç: Pamukkale Üniversitesi Tıp Fakültesi'ne Çocuklar İçin Özel Gereksinim Raporu (ÇÖZGER) için başvuran 764 çocuğun; özel gereksinim düzeyleri, ruhsal tanıları, ek fiziksel hastalıkları ve birbirleri ile ilişkilerinin araştırılması ve sonuçların ruh sağlığı alanında yapılacak yeni çalışmalara katkı sağlaması amaçlanmıştır.

Gereç ve yöntem: Nisan 2019-Ağustos 2020 tarihleri arasında Pamukkale Üniversitesi Tıp Fakültesi Çocuk ve Ergen Psikiyatrisi Sağık Kurulu Polikliniği'ne başvuran 0-18 yaş aralığında 764 olgunun verileri retrospektif olarak taranmıştır.

Bulgular: Çalışmaya yaş ortalaması ise $7,88 \pm 4,5$ yıl olan 764 olgu alındı. Olguların Ankara Gelişim Testi Envanteri (AGTE), Wechsler Çocuklar için Zeka Ölçeği-Gözden geçirilmiş formu (WISC-R) ve Wechsler Yetişkin Zekâ Ölçeği-Düzenlenmiş (WAIS-R) sonuçları cinsiyet açısından karşılaştııılığında aralarında istatistiksel olarak anlamlı bir farklıık bulunamamıştır. 6 yaş altında AGTE uygulanan olguların alt testleri incelendiğinde erkeklerde kaba motor alanda gelişim geriliğinin daha fazla olduğu bulunmuştur. ÇÖZGER'de olguların en sık gecikmiş dönüm noktası tanısı aldığı, en sık raporlanan özel gereksinim düzeyinin "Özel Gereksinimi Var" (ÖGV) olduğu, olguların özel gereksinim düzeyine göre cinsiyet açısından karşılaştıııldığında "Özel Koşul Gereksinimi Var" (ÖKGV) özel gereksiniminin erkek çocuklarda istatistiksel olarak anlamlı şekilde yüksek bulunduğu, Otizm Spektrum Bozukluğu (OSB) tanısının erkek cinsiyette anlamlı olarak daha yüksek olduğu, olguların ek tanılarının en sık olarak epilepsi ve serebral palsi olduğu saptanmıştır. Olguların cinsiyetlerine göre ek tanıları incelendiğinde; erkek çocukların istatistiksel olarak anlamlı şekilde kız çocuklara göre daha fazla genetik hastalığa sahip olduğu bulunmuştur.

Sonuç: Çocuk psikiyatri uzmanları ve çocuklar ile ilgilenen tüm hekimlerin özel gereksinimi olan çocukların hem eğitim hem de sosyal haklarını sağlamak adına uygun yönlendirmeleri yapmaları gereklidir. Bu nedenle de ülkemizde çocuklar ile çalışan hekimlerin ÇÖZGER ile ilgili yeterli seviyede bilgi sahibi olması gerekmektedir.

Anahtar kelimeler: ÇÖZGER, sağlık kurulu, çocuk, ergen.

Aktaş Terzioğlu M, Büber A, Tanrıverdi Ç, Şenol H. Çocuklar için özel gereksinim raporu başvurusu olan olguların özel gereksinim düzeyleri. Pam Tıp Derg 2022;15:77-85.

\begin{abstract}
Purpose: This study aimed to investigate 764 children who applied to Pamukkale University Faculty of Medicine for the Special Needs Report, in terms of special needs levels, mental health diagnoses, additional physical illnesses, and their relevance to each other. The outcomes are intended to contribute to new studies in the field of medical health care.

Materials and methods: A retrospective examination was made of the data of 764 children, aged between 0-18 years, who presented at the Child and Adolescent Psychiatry Health Board Polyclinic of Pamukkale University Medical Faculty between April 2019 and August 2020.

Results: Evaluation was made of 764 cases with a mean age of $7.88 \pm 4.5$ years. No difference was determined between the genders in respect of the Ankara Development Screening Inventory (ADSI), Wechsler Intelligence Scales for Children-Revised (WISC-R), and Wechsler Adult Intelligence Scale-Revised (WAIS-R) results. In the subtests of the AGTE applied to cases aged $<6$ years, there was found to be greater retarded development of gross motor skills in boys. In the SNRC, the most frequently delayed turning point of the cases was diagnosed, and the most reported special needs level was Special Needs Present" (SNP). When comparisons of the special needs level were made according to gender, the rate of "Special Conditions Needs Present" (SCNP) was determined to be statistically significantly higher in boys. Autism Spectrum Disorder was diagnosed at a statistically significantly higher rate in boys, and the most frequent additional diseases were determined to be epilepsy and cerebral palsy. In the examination of additional diseases according to gender, genetic diseases were determined at a statistically significantly higher rate in boys than girls.
\end{abstract}

Merve Aktaş Terzioğlu, Dr. Öğr. Üye. Pamukkale Üniversitesi Tıp Fakültesi Çocuk ve Ergen Ruh Sağlığı ve Hastalıkları Anabilim Dalı, Denizli, Türkiye, e-posta: merveaktasterzioglu@gmail.com (https://orcid.org/0000-0002-7668-8222) (Sorumlu Yazar)

Ahmet Büber, Dr. Öğr. Üye. Pamukkale Üniversitesi Tıp Fakültesi Çocuk ve Ergen Ruh Sağlığı ve Hastalıkları Anabilim Dalı, Denizli, Türkiye, e-posta: ahmetbuber@gmail.com (https://orcid.org/0000-0001-6293-2565)

Çiğdem Tanrıverdi, Uzm. Dr. Sağlık Bilimleri Üniversitesi Erzurum Bölge Eğitim ve Araştırma Hastanesi, Erzurum, Türkiye, e-posta: dr.cigdem_ tanriverdi@hotmail.com (https://orcid.org/0000-0001-9142-1692)

Hande Şenol, Dr. Öğr. Üye. Pamukkale Üniversitesi Tıp Fakültesi Biyoistatiksel Anabilim Dalı, Denizli, Türkiye, e-posta: handesenol@gmail.com (https://orcid.org/0000-0001-6395-7924) 
Conclusion: Pediatric psychiatry specialists and all physicians involved with children must make the appropriate referrals for children with special needs to be able to provide them with both education and social rights. Therefore, physicians working with children in Turkey should have a sufficient level of knowledge about the SNRC.

Key words: SNRC, health board, child, adolescent.

Aktas Terzioglu M, Buber A, Tanrıverdi C, Senol H. Special needs levels of cases with special needs report applications for children. Pam Med J 2022;15:77-85.

\section{Giriş}

Engellilik, doğuştan veya sonradan gelişen travma veya hastalık sonucunda; zihinsel ve fiziksel yetilerde fonksiyon kaybı ve yaşamın normal gereklerine uyum sağlayamama olarak tanımlanır [1]. Engelli bir çocuğa sahip olmak; ruhsal ve maddi zorluklar, sosyal çevre ve evlilikle ilgili sorunlara yol açmaktadır. Engellilik toplumu da etkileyen bir durumdur [2, 3].

Dünya Sağlık Örgütü'nün 2004 yılı verilerine göre 0-14 yaş arasındaki çocukların ise \%0,7$\% 5,1$ 'inin engelli olduğu düşünülmektedir [4]. Ülkemizde yapılan araştırma sonuçlarına göre, 0-9 yaş grubundaki çocukların $\% 4,1$ 'i, $10-19$ yaş grubunda ise \%4,6'sı engellidir [1]. Türkiye'de çocuklar ile yapılan bir çalışmada hafif zihinsel yetersizlik \%38,1, orta zihinsel yetersizlik $\% 15,6$, ağır zihinsel yetersizlik $\% 9,8$, çok ağır zihinsel yetersizlik $\% 0,3$ olarak bulunmuştur [5].

Çocuklar fiziksel özellikleri ve eğitsel yetenekleri açısından değişiklikler gösterirler. Ancak normal gelişim gösteren çocuklar arasındaki bu farklılıklar çok belirgin değildir. Ancak özel gereksinimi olan çocukların fiziksel özellikleri ve/veya eğitsel yetenekleri, bireysel eğitim programları ile desteklenmelidir. Özel gereksinimi olan çocukların çeşitli alanlarda yetersizlikleri olabileceği gibi bazılarının ise normların üstünde yetenekleri olabilir. Özel eğitimin amaçları; belli alanlarda yetersizliği olan çocukları desteklemek, zorlandığı alanlarda çocuğu geliştirmek, sosyal hayata ve gündelik işlere katıımını arttırmak, üstün yetenekli olan çocukların yeteneklerini ise en üst seviyeye çıkarabilmeyi desteklemektir. Özel eğitim bireyseldir, bireye özgüdür ve bireysel farklılıklar gözetilerek uygulanması gerekmektedir [6].

Sağlık kuruluna başvuran çocuk ve ergenlerde, çocuk ve ergen ruh sağlığı bakımından; zihinsel yetersizlikler ve gelişimsel gerilikler, otizm spektrum bozuklukları (OSB), özgül öğrenme bozuklukları (ÖÖB) en sık rastlanan başvuru nedenleridir [7]. Bu nedenle çocuk ve ergen ruh sağlığı alanında çalışan uzmanların sadece tanı ve tedavi değil, gelişimsel süreçte çocukların yetersizlik yaşayabildiği alanları veya üstün yönlerini fark ederek gerekli hallerde özel eğitime yönlendirmeleri gerekmektedir.

Özel eğitim ihtiyacı olan çocuklara sunulacak eğitim ve öğretim hizmetlerinin yürütülmesine yönelik hükümler yönetmelikle belirlenmiştir. 20 Şubat 2019 tarihli 30692 sayılı Resmî Gazete'de yayınlanan Yönetmelik ile Engelli Sağlık Kurulu Rapor içeriği değişmiştir. Yeni yönetmelikle birlikte birçok değişiklik yapılmış ve raporun isimlendirmesi Çocuklar İçin Özel Gereksinim Raporu (ÇÖZGER) şeklinde düzenlenmiştir [8]. ÇÖZGER'e göre özür oranı belirtilmeksizin "özel gereksinimi var" (ÖGV) şeklinde belirtilir; belirtilerin ağırlığına göre "ÖGV", "Hafif ÖGV", "Orta ÖGV", "Belirgin ÖGV", "Çok ileri ÖGV" ve "Özel koşul gereksinimi var" (ÖKGV) ifadeleri kullanılır. Yönetmelikte geçen "Çok ileri düzeyde ÖGV", "Belirgin ÖGV" ve "ÖKGV" ile ağır engellilik durumu ifade edilir [8]. ÇÖZGER için oluşturulacak kurulda 6 daimi üye bulunmaktadır. Çocuk psikiyatri, çocuk nöroloji, çocuk cerrahi, göz hastalıkları, kulak burun boğaz hastalıkları, fiziksel tıp ve rehabilitasyon, ortopedi ve travmatoloji uzmanlık alanlarından en az 4 uzman hekim bulunmalıdır. ÇÖZGER yönetmeliğinde örnek bir rapor nüshası, ilgili branşlarla ilgili hastalıklar ve hastalıkların özel gereksinim düzeyleri belirtilmektedir [8]. ÇÖZGER kapsamında çocuk ve ergen ruh sağığı; bilişsel gelişim alanı ve çocuk-genç psikiyatri alanından oluşmaktadır. Bilişsel gelişim alanı kapsamında zekâ geriliği ve benzeri tanımlamaların kullanılmaması gerekmektedir. Eğer bireyin bu alanda bir yetersizliği var ise "gecikmiş dönüm noktası" ICD (R 62.0) tanısının kullanılması ve özel gereksinim düzeyinin belirtilmesi önerilmektedir. ÇÖZGER çocuk ve genç psikiyatri alanında ise ÖÖB, OSB, şizofreni ve diğer psikotik bozukluklar, organik beyin 
hasarına bağlı bilişsel ve ruhsal bozukluklar, duygudurum bozuklukları, anksiyete bozuklukları bulunmaktadır. ÇÖZGER'de atipik otizm tanımlaması kaldırılmış, OSB bir bütün olarak tek tanı altında toplanmıştır. Dikkat eksikliği ve hiperaktivite bozukluğu (DEHB) da ÇÖZGER tanıları içinde bulunmamaktadır [8].

Bu çalışmada, Pamukkale Üniversitesi Tıp Fakültesi Çocuk ve Ergen Psikiyatrisi Sağlık Kurulu Polikliniği'ne 01 Nisan 2019 ile 31 Ağustos 2020 tarihleri arasında başvuran 764 çocuk ve ergenin yeni bir raporlama sistemi olan "ÇÖZGER" ile ruh sağlığı bakımından özel gereksinim düzeyleri, ruhsal tanıları, ek fiziksel hastalıkları, birbirleri ile ilişkilerinin araştırılması ve sonuçların ruh sağlığı alanında yapılacak yeni çalışmalara katkı sağlaması amaçlanmıştır.

\section{Gereç ve yöntem}

01 Nisan 2019-31 Ağustos 2020 tarihleri arasında Pamukkale Üniversitesi Tıp Fakültesi Çocuk ve Ergen Psikiyatrisi Sağlık Kurulu Polikliniği'ne başvuran çocuk ve ergen yaş grubundaki (0-18 yaş) 764 olgunun verileri çalışmaya dahil edilmiştir. Çalışmamız için Pamukkale Üniversitesi Girişimsel Olmayan Klinik Araştırmalar Etik Kurulu'nun kararı ile onay alınmıştır. Olgular 20.02.2019 tarihinde Resmî Gazete'de yayımlanmış olan "Çocuklar İçin Özel Gereksinim Değerlendirmesi Hakkında Yönetmelik" esas alınarak değerlendirilmiştir [8]. 01 Nisan 2019-31 Ağustos 2020 tarihleri arasında sağlık kuruluna başvuran olguların dosyaları retrospektif olarak taranmıştır.

Hastanemizde ÇÖZGER için başvuran tüm olgular çocuk psikiyatri, çocuk nöroloji, çocuk hastalıkları, çocuk cerrahi, göz hastalıkları, kulak burun boğaz hastalıkları, fiziksel tıp ve rehabilitasyon uzmanları tarafından değerlendirilmektedir. Çocuk psikiyatri açısından değerlendirme; çocuk ve bakımveren ile klinik görüşme, çocukların gelişim düzeyini değerlendirmek için 6 yaşından küçük olgulara Ankara Gelişim Tarama Envanteri (AGTE), 6-16 yaş arasındaki çocuk ve ergenlerin zeka düzeyini değerlendirmek için Wechsler Çocuklar İçin Zekâ Ölçeği Gözden Geçirilmiş Formu (WISC-R), 16-18 yaş arası ergenlere ise Wechsler Yetişkinler İçin Zekâ Ölçeği Gözden Geçirilmiş Formu (WAIS-R) uygulanarak tamamlanmaktadır.
Ankara Gelişim Tarama Envanteri (AGTE): Sezgin ve ark. [9] (1994) tarafından 0-6 yaş çocukların gelişim düzeyini belirlemeye yönelik olarak geliştirilmiştir. AGTE 164 madde ve dört alt testten oluşmaktadır. AGTE sonucuna göre; gelişim düzeyi \%20 ile \%30 arasındaysa çocuk gelişimsel açıdan risk altındadır, gelişim düzeyi \%30'un altında ise çocukta gelişimsel gecikme mevcuttur.

Wechsler Çocuklar İçin Zekâ Ölçeği Gözden Geçirilmiş Formu (WISC-R): Wechsler (1949) tarafından geliştirilen Wechsler Çocuklar için Zekâ Ölçeğinin (WISC) revize edilmiş versiyonudur. WISC-R, performans ve sözel alt testlerden oluşmaktadır. Performans alt testler; şifre, küplerle desen, parça birleştirme, resim düzenleme ve resim tamamlamadan oluşur. Sözel Alt testler ise genel bilgi, yargılama, aritmetik, benzerlikler, sayı dizilerinden oluşur. Savaşır ve Şahin (1995) tarafından 6-16 yaş aralığında standardizasyonu yapıımıştır [10].

Wechsler Yetişkinler İçin Zekâ Ölçeği Gözden Geçirilmiş Formu (WAIS-R): Yetişkinlerin zekasını ölçmek için ilk olarak 1955 'te WAIS, 1981 'de ise WAIS-R geliştirilmiştir. 16 yaş ve üstü için kullanılan bir zekâ testidir. Bu testin 11 alt testten ( 6 sözel ve 5 performans alt test) oluşmaktadır [11].

Veriler SPSS 25.0 paket programıyla analiz edilmiştir. Tanımlayıcı bilgiler sayı (n) ve yüzdeler (\%) ile ifade edilmiştir. Değişkenler arasındaki farklılıkların incelenmesinde ise $\mathrm{Ki}$ kare testi kullanılmıştır. Tüm analizlerde $p<0,05$ istatistiksel olarak anlamlı kabul edilmiştir.

\section{Bulgular}

Çalışmaya yaş ortalaması ise $7,88 \pm 4,5$ yıl olan 764 olgu alındı. Olguların \%39,3'ü $(n=300) \quad k ı, \quad \% 60,7$ 'si $\quad(n=464)$ erkekti. Olguların sosyodemografik bilgileri Tablo 1'de gösterilmiştir. Çalışmamızda olguların \%37'sine $(n=283)$ AGTE, \%58,2'sine $(n=445)$ WISC-R, $\% 4,7$ 'sine $\quad(n=36) \quad$ WAIS- $R$ uygulanmıştır. Çalışmamızda 6 yaş-16 yaş arası olgulara WISC-R, 16 yaş ve üzeri olan olgulara WAIS-R testi uygulanmıştır. Olguların WISC-R ve WAIS-R sonuçları incelendiğinde; \%32,4'ünün $(n=158)$ normal SD, \%19,3'ünün ( $n=94)-1 S D$, $\% 11,5$ 'inin ( $n=56)-1,5$ SD, \%4,9'unun ( $n=24)$ $-2,5$ SD ve \%7'sinin $(n=34)$ ise -3 SD aralığında olduğu bulunmuştur. Olgular test sonuçlarına 
göre cinsiyet açısından karşılaştırıldığında aralarında istatistiksel olarak anlamlı bir farklılık bulunamamıştır. Olguların cinsiyetlerine göre WISC-R/WAIS-R sonuçları Tablo 2'de gösterilmiştir.

Çalışmamızda 6 yaşın altındaki olgulara AGTE uygulanmıştır. AGTE sonucu incelendiğinde; olguların \%76,3'ünde $(n=216)$ genel gelişim alanında, \%77,7'sinde $(n=220)$ dil bilişsel alanda, \%72,1'inde $(n=204)$ ince motor alanda, \%54,1'inde $(n=153)$ kaba motor alanda ve \%68,9'unda ( $n=195)$ sosyal beceri/öz bakım alanında \%30'un altında gelişim geriliği olduğu saptanmıştır. 6 yaş altında AGTE uygulanan olguların alt testleri incelendiğinde erkeklerde kaba motor alanda gelişim geriliğinin daha fazla olduğu bulunmuş, ancak AGTE testinde cinsiyetler arasında istatistiksel olarak anlamlı farklılık saptanmamıştır. Olguların cinsiyetlerine göre AGTE sonuçları Tablo 3'te gösterilmiştir.

Tüm başvurular değerlendirildiğinde \%39,6'sında $\quad(n=303)$ gecikmiş dönüm noktası, \%20,4'ünde ( $n=156)$ ÖÖB, \%8,5'inde $(n=65)$ OSB, \%2,4'ünde $(n=18)$ Aktivite ve Dikkat Bozukluğu, \%1'inde $(n=8)$ Anksiyete Bozukluğu, \%0,8'inde ( $n=6)$ Depresif Bozukluk, $\% 0,1$ 'inde $(n=1)$ Duygudurum Bozukluğu tespit edilmiştir. Olguların \%27,22'sinde $(n=208)$ ise psikiyatrik bozukluk saptanmamıştır. OSB erkek cinsiyette anlamlı olarak daha yüksek saptanmıştır $(p=0,008)$ ÇÖZGER için başvuran olguların aldıkları tanılara göre sayı ve yüzdelik

Tablo 1. Olguların yaş, cinsiyet ve doğuma ait bilgileri

\begin{tabular}{llll}
\hline & & $\mathbf{n}$ & \% \\
\hline Yaş & $\mathbf{6}$ yaşından küçük & 273 & 35,7 \\
Cinsiyet & $\mathbf{6}$ yaşından büyük & 491 & 64,3 \\
& Kız & 300 & 39,3 \\
Doğum zamanı & Erkek & 464 & 60,7 \\
& Preterm & 142 & 18,6 \\
& Term & 597 & 78,0 \\
& Postterm & 6 & 0,8 \\
Doğum ağırlığı & Hatırlanmıyor & 20 & 2,6 \\
& $\mathbf{1 0 0 0}$ gr'dan düşük & 12 & 1,6 \\
& $\mathbf{1 0 0 0 - 1 5 0 0}$ gr arası & 27 & 3,5 \\
& $\mathbf{1 5 0 0 - 2 5 0 0}$ gr arası & 106 & 13,9 \\
& $\mathbf{2 5 0 0 - 4 0 0 0}$ gr arası & 526 & 68,8 \\
& $\mathbf{4 0 0 0}$ gr'ın üstü & 25 & 3,3 \\
& Hatırlanmıyor & 68 & 8,9 \\
\hline
\end{tabular}

Tanımlayıcı istatistikler $n$ (sayı) ve \% (yüzde) ile ifade edilmiştir

Tablo 2. Olguların cinsiyetlerine göre WISC-R/WAIS-R sonuçları

\begin{tabular}{llllll}
\hline & Kız n (\%) & Erkek n (\%) & Toplam n (\%) & p \\
\hline & Normal (85-114) & $58(\% 30,21)$ & $100(\% 33,78)$ & $158(\% 32,38)$ & \\
& -1 SD (70-84) & $39(\% 20,31)$ & $55(\% 18,58)$ & $94(\% 19,26)$ & \\
& -1,5 SD (62-69) & $26(\% 13,54)$ & $30(\% 10,14)$ & $56(\% 11,48)$ & \\
WISC-RI & -2 SD (55-61) & $12(\% 6,25)$ & $16(\% 5,41)$ & $28(\% 5,74)$ & \\
WAIS-R & -2,5 SD (47-54) & $11(\% 5,73)$ & $13(\% 4,39)$ & $24(\% 4,92)$ & 0,690 \\
& -3 SD (40-46) & $9(\% 4,69)$ & $25(\% 8,45)$ & $34(\% 6,97)$ & \\
& +1 SD (115-129) & $6(\% 3,13)$ & $6(\% 2,03)$ & $12(\% 2,46)$ & \\
& +2 SD (130 ve üstü) & $1(\% 0,52)$ & $1(\% 0,34)$ & $2(\% 0,41)$ & \\
& Testi Alamadı & $30(\% 15,63)$ & $50(\% 16,89)$ & $80(\% 16,39)$ & \\
\hline
\end{tabular}

Ki-kare testi. SD: standart sapma

WISC-R: Wechsler Çocuklar için Zeka Ölçeği -Gözden geçirilmiş formu

WAIS-R: Wechsler Yetişkin Zekâ Ölçeği-Düzenlenmiş 
Tablo 3. Olguların cinsiyetlerine göre AGTE sonuçları

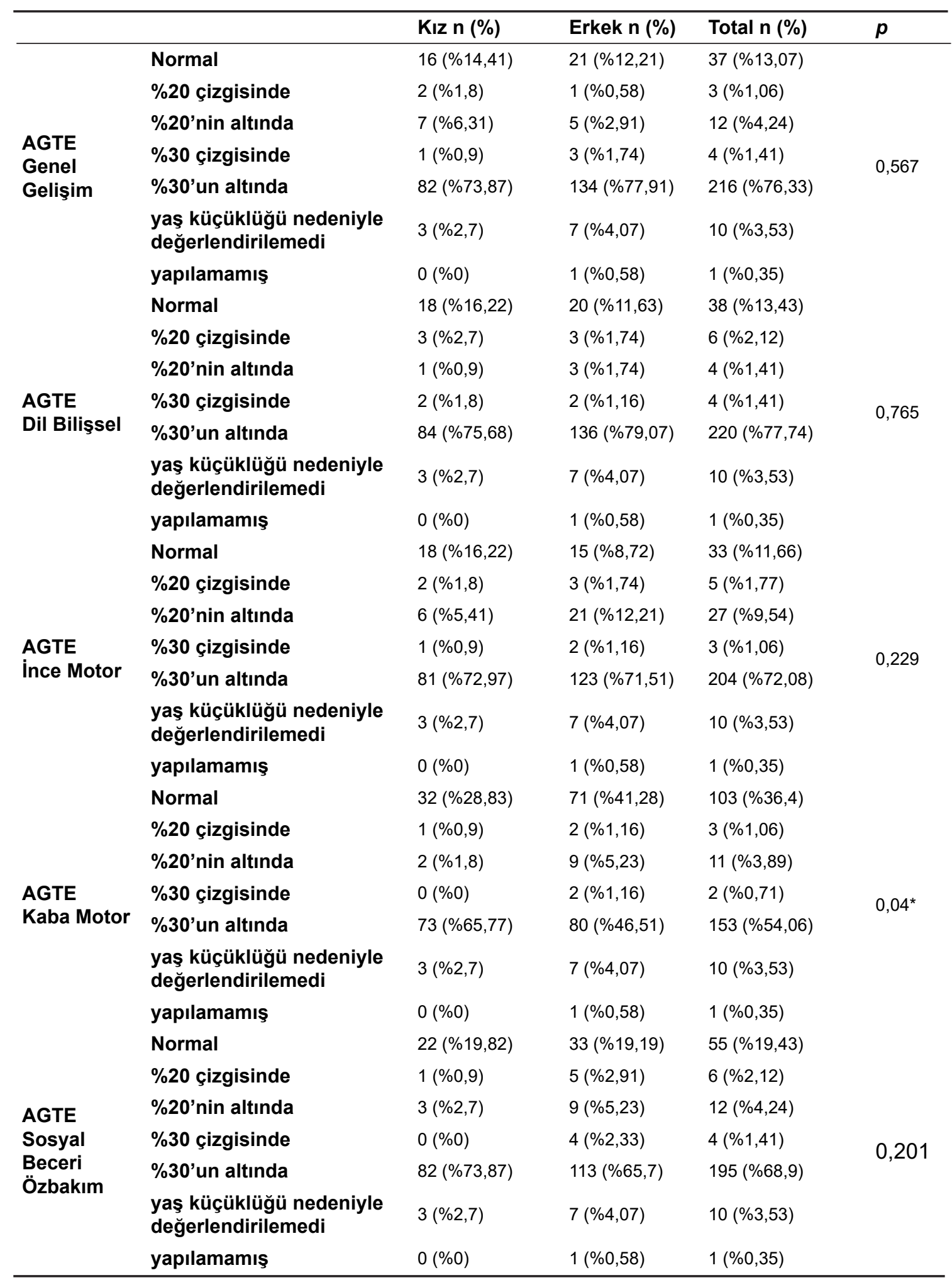

$p<0,05$ istatistiksel olarak anlamlı; Ki-kare testi AGTE: Ankara Gelişim Testi Envanteri 
oranları tabloda verilmiştir. Olguların tanılarının cinsiyetlerine göre sınıflandırılması Tablo 4'te gösterilmiştir.

Olguların \%40,3'ü (n=308) ÖGV, \%14,4'ü $(n=110)$ orta düzeyde ÖGV ve $\% 5,8$ 'i $(n=44)$ ise çok ileri düzey ÖGV, olguların \%10,3'ü $(n=79)$ ise ÖKGV olarak bulunmuştur. Olgular özel gereksinim düzeyine göre cinsiyet açısından karşılaştırıldığında "ÖKGV" özel gereksiniminin erkek çocuklarda istatistiksel olarak anlamlı şekilde yüksek bulunduğu saptanmıştır $(p=0,005)$. Olguların cinsiyetlere göre özel gereksinim düzeyleri Tablo 5'te gösterilmiştir.

ÇÖZGER raporu için başvuran olguların ek tanıları incelendiğinde, \%11,1'inde $(n=85)$ genetik hastalığın olduğu, \%9,7'sinde ( $n=74)$ epilepsi olduğu, \%8,5'inde $(n=65)$ diğer nörolojik hastalıklar, \%6,8'inde $(n=52)$ serebral palsi, \%5,1'inde ( $n=39)$ işitme kaybı, \%3,8'inde ( $n=29)$ konuşma bozukluğu, \%2,9'unda ( $n=22)$ görme kaybının olduğu saptanmıştır. Olguların cinsiyetlerine göre ek tanıları incelendiğinde; erkek çocukların istatistiksel olarak anlamlı şekilde kız çocuklara göre daha fazla genetik hastalığa sahip olduğu bulunmuştur $(p=0,012)$. Diğer ek tanıların varlığı açısından cinsiyetler arasında istatistiksel olarak anlamlı bir farklılık bulunamamıştır. Olguların ek tanılarının cinsiyetlerine göre sınıflandırılması Tablo 6'da gösterilmiştir.

Tablo 4. Olguların tanılarının cinsiyetlerine göre sınıflandırılması

\begin{tabular}{lllll}
\hline TANILAR & Kız n (\%) & Erkek n (\%) & Total n (\%) & p \\
\hline Özgül Öğrenme Bozukluğu & $60(\% 20)$ & $96(\% 20,69)$ & $156(\% 20,42)$ & \\
Dikkat Eksikliği Hiperaktivite Bozukluğu & $6(\% 2)$ & $12(\% 2,59)$ & $18(\% 2,36)$ & \\
Otizm Spektrum Bozukluğu & $12(\% 4)$ & $52(\% 11,21)$ & $64(\% 8,38)$ & \\
Gecikmiş Dönüm Noktası & $126(\% 42)$ & $177(\% 38,15)$ & $303(\% 39,66)$ & $0,008^{*}$ \\
Normal Psikiyatrik Muayene & $89(\% 29)$ & $121(\% 26,07)$ & $208(\% 27,22)$ & \\
Anksiyete Bozukluğu & $4(\% 1,33)$ & $4(\% 0,86)$ & $8(\% 1,05)$ & \\
Major Depresif Bozukluk & $5(\% 1,67)$ & $1(\% 0,22)$ & $6(\% 0,79)$ & \\
Duygudurum Bozukluğu & $0(\% 0)$ & $1(\% 0,22)$ & $1(\% 0,13)$ & \\
\hline
\end{tabular}

$p<0,05$ istatistiksel olarak anlamlı; Ki-kare testi

Tablo 5. Olguların cinsiyetlere göre özel gereksinim düzeyleri

\begin{tabular}{lllll}
\hline & Kız n (\%) & Erkek n (\%) & Toplam n (\%) & $p$ \\
\hline ÖGV & $121(\% 40,33)$ & $187(\% 40,3)$ & $308(\% 40,31)$ & \\
Orta ÖGV & $50(\% 16,67)$ & $60(\% 12,93)$ & $110(\% 14,4)$ & \\
Çok İleri ÖGV & $20(\% 6,67)$ & $24(\% 5,17)$ & $44(\% 5,76)$ & $0,005^{*}$ \\
ÖKGV & $16(\% 5,33)$ & $63(\% 13,58)$ & $79(\% 10,34)$ & \\
Oran Yok & $93(\% 31)$ & $130(\% 28,02)$ & $223(\% 29,19)$ & \\
\hline
\end{tabular}

$p<0,05$ istatistiksel olarak anlamlı; Ki-kare testi

ÖGV: Özel Gereksinimi Var, ÖKGV: Özel Koşul Gereksinimi Var 
Tablo 6. Olguların ek tanılarının cinsiyetlerine göre sınıflandırılması

\begin{tabular}{|c|c|c|c|c|c|}
\hline & & Kız n (\%) & Erkek n (\%) & Toplam n (\%) & \\
\hline \multirow{2}{*}{ Serebral Palsi } & Var & $26(\% 8,67)$ & $26(\% 5,6)$ & $52(\% 6,81)$ & \multirow{2}{*}{0,101} \\
\hline & Yok & $274(\% 91,33)$ & $438(\% 94,4)$ & $712(\% 93,19)$ & \\
\hline \multirow{2}{*}{ Epilepsi } & Var & $32(\% 10,67)$ & $42(\% 9,05)$ & $74(\% 9,69)$ & \multirow{2}{*}{0,461} \\
\hline & Yok & $268(\% 89,33)$ & $422(\% 90,95)$ & $690(\% 90,31)$ & \\
\hline \multirow{2}{*}{ Genetik Hastalık } & Var & $44(\% 14,67)$ & $41(\% 8,84)$ & $85(\% 11,13)$ & \multirow{2}{*}{$0,012^{*}$} \\
\hline & Yok & $256(\% 85,33)$ & $423(\% 91,16)$ & $679(\% 88,87)$ & \\
\hline \multirow{2}{*}{ İşitme Kaybı } & Var & $21(\% 7)$ & $18(\% 3,88)$ & $39(\% 5,1)$ & \multirow{2}{*}{0,056} \\
\hline & Yok & $279(\% 93)$ & $446(\% 96,12)$ & $725(\% 94,9)$ & \\
\hline \multirow{2}{*}{ Görme Kaybı } & Var & $7(\% 2,33)$ & $15(\% 3,23)$ & $22(\% 2,88)$ & \multirow{2}{*}{0,468} \\
\hline & Yok & $293(\% 97,67)$ & $449(\% 96,77)$ & $742(\% 97,12)$ & \\
\hline \multirow{2}{*}{$\begin{array}{l}\text { Konuşma } \\
\text { Bozukluğu }\end{array}$} & Var & $8(\% 2,67)$ & $21(\% 4,53)$ & $29(\% 3,8)$ & \multirow{2}{*}{0,189} \\
\hline & Yok & $292(\% 97,33)$ & $443(\% 95,47)$ & $735(\% 96,2)$ & \\
\hline \multirow{2}{*}{$\begin{array}{l}\text { Diğer Nörolojik } \\
\text { Hastalıklar }\end{array}$} & Var & $23(\% 7,67)$ & $42(\% 9,05)$ & $65(\% 8,51)$ & \multirow{2}{*}{0,503} \\
\hline & Yok & $277(\% 92,33)$ & $422(\% 90,95)$ & $699(\% 91,49)$ & \\
\hline \multirow{2}{*}{ Diğer Hastalıklar } & Var & $120(\% 40)$ & $187(\% 40,3)$ & $307(\% 40,18)$ & \multirow{2}{*}{0,934} \\
\hline & Yok & $180(\% 60)$ & $277(\% 59,7)$ & $457(\% 59,82)$ & \\
\hline
\end{tabular}

$p<0,05$ istatistiksel olarak anlamlı; Ki-kare testi

\section{Tartışma}

01 Nisan 2019-31 Ağustos 2020 tarihleri arasında Pamukkale Üniversitesi Tıp Fakültesi Çocuk ve Ergen Psikiyatrisi Sağlık Kurulu Polikliniği'ne başvuran çocuk ve ergen yaş grubundaki (0-18 yaş) 764 olgunun ÇÖZGER raporları retrospektif olarak taranmıştır. Tüm başvurular değerlendirildiğinde; çocuk ve ergen ruh sağıı̆ı açısından en sık "gecikmiş dönüm noktası” tanısının konulduğu, ÇÖZGER'de çocuk ve ergen ruh sağlığı açısından en sık verilen özel gereksinim düzeyinin "ÖGV" olduğu bulunmuştur. Başvuran 764 olgudan 208'inin $(\% 27,22)$ psikiyatrik değerlendirmesi normal olarak bulunmuş, 223'ü $(\% 29,1)$ çocuk psikiyatri bölümünden oran almamıştır. Bu aradaki fark bazı psikiyatrik tanıların "ÖGV" olarak karşılığı olmamasından kaynaklanmaktadır. Örneğin DEHB tanıSı ICD tanısı olarak raporda kodlanır ancak yönetmelikte özel gereksinim gerekliliği yoktur [8]. Literatürde ÇÖZGER'den önceki sağlık kurulu yönetmeliğine göre çocuklarla yapılmış olan çalışmalar mevcuttur [5, 7, 12-14]. Alan yazın taranınca ÇÖZGER ile ilgili çocuk ve ergen ruh sağlığı alanında ülkemizde yapılan az sayıda çalışma olduğu görülmüştür $[6,15]$.

Çalışmamızdaki erkek/kız cinsiyet oranı 1,5 olarak saptanmıştır. Bu oran OSB, ÖÖB ve zihinsel yetersizliklerin erkek cinsiyette daha sık görülmesi ile açıklanabilir. Bizim çalışmamızla benzer şekilde Kaplan [12] (2017) da erkek/ kız oranını 1,4 olarak saptamıştır. Bu alanda yapılan diğer iki çalışmada 1,6 [5, 13], bir başka çalışmada ise bu oran 2 olarak bulunmuştur [14]. ÇÖZGER ile ilgili olarak yapılan iki çalışmada da cinsiyet bakımından elde edilen veriler çalışmamız sonuçlarına paraleldir [3, 6]. TUIKK (2010) ve DíE (2004) verilerine göre engelli nüfus içinde erkek cinsiyet daha yüksek oranda bulunmaktadır [1, 16]. Çalışmamızda bulunan sonuç alan yazınla uyumludur.

Çalışmamızda çocuk ve ergen ruh sağlığı açıdan en sık konulan tanı "gecikmiş dönüm noktası" tanısıdır. ÇÖZGER ile ilgili yönetmelikte, bilişsel gelişimde gecikme ve zihinsel yetersizlik tanıları yerine gecikmiş dönüm noktası tanısı konulması önerilmiştir. ÇÖZGER ile ilgili çocuk ve ergen ruh sağlığı alanında yapılan ilk çalışma olan Kayhan ve Öztürk [6] (2020) yaptığı çalışmada da "gecikmiş dönüm noktası" tanısı olguların aldığı en sık tanı olarak bulunmuştur. ÇÖZGER ile ilgili kulak burun boğaz hastalıkları alanında yapılan çalışmada da ruhsal alanda en sık alınan tanı gecikmiş dönüm noktasıdır [3]. Türkiye'de çocuk sağlık kurulları ile yapılan diğer iki önemli çalışmada da zihinsel yetersizlik sırasıyla \%52,4 ve \%64 oranında görülmüştür $[14,17]$. Çalışmamızda elde edilen veri bu sonuçlara benzerdir. 
Çalışmamızda; olgular özel gereksinim düzeyine göre incelendiğinde "ÖGV"nin en sık verilen özel gereksinim çeşidi olduğu görülmüştür. ÖÖB ve gecikmiş dönüm noktası tanısının sık görülmesi ile bu durum açıklanabilir. ÇÖZGER'de ÖÖB tanısına “ÖGV” verilmektedir. Gecikmiş dönüm noktası tanısında özellikle 6 yaş altı çocuklarda sıklıkla sınır düzeyde bilişsel gelişimde gecikme ile uyumlu olarak "ÖGV" özel gereksinim düzeyi verilmektedir. Cinsiyet açısından karşılaştırıldığında "ÖKGV" özel gereksiniminin erkek çocuklarda istatistiksel olarak anlamlı şekilde yüksek bulunduğu saptanmıştır $(p=0,005)$. Bunun nedeni literatürle uyumlu olarak çalışmamızda da OSB ve genetik hastalıkların daha fazla oranda erkek cinsiyette görülmesi ile açıklanabilir [18-21].

Olguların ek tanıları incelendiğinde, $\% 11,1$ 'inde genetik hastalık olduğu, \%9,7'sinde epilepsi olduğu, \%8,5'inde diğer nörolojik hastalıklar, \%6,8'inde serebral palsi, \%5,1'inde işitme kaybı, \%3,8'inde konuşma bozukluğu, \%2,9'unda görme kaybı olduğu saptanmıştır. Olguların ek tanılarında en sık nörolojik hastalıklar bulunmaktadır. Nörolojik hastalıklar içinde en sık epilepsi, ikinci sırada ise serebral palsi görülmektedir. Kayhan ve Öztürk [6] (2020) ÇÖZGER ile ilgili yaptıkları çalışmada da benzer şekilde ek tanı olarak nörolojik hastalıklar ilk sırada yer almıştır. Benzer şekilde diğer çalışmalarda da olguların en fazla nörolojik ek tanılarının bulunduğu, serebral palsi ve epilepsinin en sık saptanan nörolojik hastalıklar olduğu saptanmıştır [5, 14]. Çalışmamızda elde ettiğimiz veriler bu sonuçlar ile uyumludur.

Olguların cinsiyetlerine göre ek tanıları incelendiğinde; erkek çocukların istatistiksel olarak anlamlı şekilde kız çocuklara göre daha fazla genetik hastalığa sahip olduğu bulunmuştur $(p=0,012)$. Diğer ek tanıların varlığı açısından cinsiyetler arasında istatistiksel olarak anlamlı bir farklılık bulunamamıştır. X kromozomuna bağlı oluşan genetik hastalıklar bu farklıığın nedeni olabilir. ÇÖZGER ile değişen yönetmelik ile kalıtsal ve doğumsal hastalıklar "ÖKGV" almaya başlamıştır [8]. Yönetmelikte geçen "Çok ileri düzeyde ÖGV", "Belirgin ÖGV" ve "ÖKGV" ile ağır engellilik durumu ifade edilerek, özel eğitim dışında; evde bakım ücreti almak, vergi indiriminden yararlanmak gibi haklar da elde edilebilmektedir [8].
Çalışmamızda nörolojik hastalıklardan sonra en sık işitme, dil-konuşma bozuklukları ve görme bozuklukları ek tanıları saptanmıştır. Yektaş ve Kaplan [12] (2017) yaptıkları çalışmada da benzer bulgular elde edilmiştir.

Çalışmamızın tek merkezde retrospektif olarak verilerin incelenmesi çalışmayı sınırlandırmış olabilir. Bu kısıtılığa rağmen çalışmamız; ÇÖZGER ile ilgili yapılan az sayıdaki çalışmalardan biri olması ve katılımcı sayısının yüksek olması nedeni ile diğer merkezler için yapılacak çalışmalara ve özel gereksinimi olan çocuklar ile ilgilenen çocuk psikiyatri uzmanlarına yol gösterici olacaktır.

Sonuç olarak; çocuk psikiyatri uzmanları ve çocuklar ile ilgilenen tüm hekimlerin özel gereksinimi olan çocukların hem eğitim hem de sosyal haklarını sağlamak adına uygun yönlendirmeleri yapmaları gereklidir. Bu nedenle de ülkemizde çocuklar ile çalışan hekimlerin ÇÖZGER kurulları ile ilgili yeterli seviyede bilgi sahibi olması gerekmektedir. Daha çok merkezde çalışmaların yapılması ile ülkemiz için sağlıklı veriler elde edilebilir, klinik yaklaşım önerileri geliştirilebilir. Verilerimizin ülkemizde yapılacak çalışmalar için katkı sağlayacağı düşünülmektedir.

Çıkar ilişkisi: Yazarlar çıkar ilişkisi olmadığını beyan eder.

\section{Kaynaklar}

1. Devlet İstatistik Enstitüsü/Özürlüler İdaresi Başkanlığı. Türkiye Özürlüler Araştırması 2002 (İkinci baskı). Ankara: Devlet İstatistik Enstitüsü Matbaası, 2009. Available at: http:/leski.bingol. edu.tr/media/225884/15TuRKiYEoZuRLuLERARAsTiRMASi.pdf. Accessed April 14, 2021

2. Kaya A, Güler H, Meral O, Aktaş EÖ. The retrospective examination of the reports for the children with disabilities prepared by the Disability Board of Ege University Medical School. J Curr Pediatr 2014;12:151159. https://doi.org/10.4274/jcp.96967

3. Kumbul YÇ, Sivrice ME, Akın V. Çocuklar için özel gereksinim raporunda (ÇÖZGER) kulak burun boğaz hastalıklarının önemi ve başvuran hastaların klinik özelliklerinin değerlendirilmesi. SDÜ Sağlık Bilimleri Dergisi 2020;11:348-352. https://doi.org/10.22312/ sdusbed. 774847

4. World Health Organization (WHO). World report on dısabılıty. Geneva. 2011. Available at: https://www.who. int/disabilities/world_report/2011/report.pdf. Accessed April 14, 2021 
5. Başgül ŞS, Saltık S. Göztepe Eğitim ve Araştırma Hastanesi-Özürlü Çocuk Heyeti'nin 2010 yılı verileri. Göztepe Tıp Derg 2012;27:45-49. https://doi. org/10.5222/J.GOZTEPETRH.2012.045

6. Kayhan M, Öztürk Y. Clinical and sociodemographic characteristics of cases presenting to an university hospital for special need reports for children. Osmangazi J Med 2020;42:240-248. https://doi. org/10.20515/otd.661980

7. Özbaran B, Köse S. Çocuk psikiyatrisi pratiğinde özürlü sağlık kurulu raporları; 6 yıllık Ege Üniversitesi deneyimi. Çocuk ve Gençlik Ruh Sağlığı Derg 2011;18:67-72.

8. Çocuklar İçin Özel Gereksinim Değerlendirmesi Hakkında Yönetmelik, 2019, 30692 mükerrer. Available at: https://www.resmigazete.gov.tr/ eskiler/2019/02/20190220-1.htm. Accessed April 14,2021

9. Sezgin N, Savaşır I, Erol N. Ankara gelişim tarama envanteri el kitabı. 1. Basım. Ankara: Rekmay, 1994.

10. Savaşır I, Şahin N. Wechsler çocuklar için zeka ölçeği uygulama kitapçığı. (Savaşır I, Şahin N, Çev.) Ankara: Türk Psikologlar Derneği,1995.

11. Wechsler D. WAIS-R Manual: Wechsler adult intelligence scale-revised. New York: The Pschological Corporation, 1981.

12. Yektaş Ç, Kaplan SE. Bir üniversite hastanesi çocuk ergen ruh sağlığı ve hastalıkları birimi'ne başvuran hastaların sağlık kurulu raporlarının değerlendirilmesi. Konuralp Tıp Dergisi 2017;9:52-56. https://doi. org/10.18521/ktd.346073

13. Gümüş YY, Yürümez E. Assessment of the applications to Kocaeli Derince Research and Education Hospital in 2012 and 2013 to obtain disabled children's health board report. J Exp Clin Med 2014;31:231-235. https:// doi.org/10.5835/jecm.omu.31.04.006

14. Şahin N, Altun H, Kara B. Assessment of disabled child health council reports. Kocatepe Med J 2014;15:48-53.

15. Yıldız D, Tarakçıoğlu MC. Çocuklar için özel gereksinim raporu (ÇÖZGER) almak için başvuran hastaların klinik özellikleri, eş tanılarının incelenmesi, yeni değişen ÇÖZGER yönetmeliğine göre aldıkları tanı ve özür oranlarının eski tanı ve özür oranları ile karşıllaştırılması. IKSSTD 2020;12:144-150. https://doi. org/10.5222/iksstd.2020.14632

16. Türkiye İstatistik Kurumu (TÜİK). Özürlülerin sorun ve beklentileri araştırması, 2010. Ankara: Türkiye İstatistik Kurumu Matbaası, 2011. Available at: https://tuikweb. tuik.gov.tr/HbPrint.do?id=6370. Accessed April 14, 2021

17. Öztürk Y, Demir N, Topal Z, Savci U, Cansız MA, Tufan AE. Bir üniversite hastanesine engelli çocuk sağlık kurulu için başvuran olguların klinik ve sosyodemografik özellikleri: bir ön çalışma. Çocuk ve Gençlik Ruh Sağlığı Dergisi 2018;25:101-110.
18. Evans SC, Boan AD, Bradley C, Carpenter LA. Sex/ Gender differences in screening for autism spectrum disorder: ımplications for evidence-based assessment. J Clin Child Adolesc Psychol 2019;48:840-854. https:// doi.org/10.1080/15374416.2018.1437734

19. Loomes R, Hull L, Mandy WPL. What is the male-tofemale ratio in autism spectrum disorder? A systematic review and meta-analysis. J Am Acad Child Adolesc Psychiatry 2017;56:466-474. https://doi.org/10.1016/j. jaac.2017.03.013

20. Werling DM, Geschwind DH. Sex differences in autism spectrum disorders. Curr Opin Neurol 2013;26:146153. https://doi.org/10.1097/WCO.0b013e32835ee548

21. Ke X, Liu J. Intellectual disability. In: Rey JM (ed), IACAPAP e-Textbook of Child and Adolescent Psychiatry and Allied Professions. Geneva. 2012. Available at: https://iacapap.org/content/uploads/C.1Intellectual-Disability.pdf. Accessed April 15, 2021

Etik kurul onayı: Pamukkale Üniversitesi Girişimsel Olmayan Klinik Araştırmalar Etik Kurulu'nun 27.10.2020 tarih ve 20 sayılı kararı ile onay alınmıştır.

\section{Yazarların makaleye olan katkıları}

M.A.T. ve A.B. çalışmanın ana fikrini ve hipotezini kurgulamışlardır. M.A.T., A.B. ve Ç.T. teoriyi geliştirmiş, gereç ve yöntem bölümünü düzenlemişlerdir. Veri toplama M.A.T. ve Ç.T. tarafından, veri analizi H.Ş. tarafından yapıımıştır. Sonuçlar kısmındaki verilerin değerlendirmesini M.A.T., A.B., Ç.T. ve H.Ş. yapmışlardır. Makalenin tartışma bölümü M.A.T. tarafından yazılmış, A.B., Ç.T. ve H.Ş. gözden geçirip gerekli düzeltmeleri yapmış ve onaylamıştır. Ayrıca tüm yazarlar çalışmanın tamamını tartışmış ve son halini onaylamıştır. 